\title{
Multi-accretional tectonics at the Rio de la Plata Craton margins: preface
}

\author{
Siegfried Siegesmund • Miguel Basei • \\ Pedro Oyhantçabal
}

Received: 4 October 2010/Accepted: 1 November 2010/Published online: 19 November 2010

(C) The Author(s) 2010. This article is published with open access at Springerlink.com

This special issue is the result of exchange and cooperation over the last decade between scientific groups working on the geology of Gondwana in South America and Southern Africa.

The Rio de la Plata Craton (RPC) is of special importance in the amalgamation of Western Gondwana, because Neoproterozoic to Eopaleozoic mobile belts of South America and Africa resulted from the fusion of different cratonic blocks against the RPC. The collision of the Congo and Kalahari cratons to the eastern margin of the RPC resulted in the Dom Feliciano, Kaoko and Gariep belts, while convergence of the Pampean Terrane in the western margin is associated with the Pampean Orogen and the docking of Cuyania and Chilenia.

The present day area of the RPC is about one million $\mathrm{km}^{2}$, but most of the craton is covered by Phanerozoic sediments and the basement is only exposed in two main areas: (1) the Piedra Alta Terrane of southwestern Uruguay and (2) the Tandilia Belt of Argentina (see discussion in Oyhantcabal this volume). Sm-Nd model ages indicate the RPC is composed of juvenile crust of Neoarchean to Palaeoproterozoic age followed by a short period of crustal reworking. U-Pb SHRIMP zircon crystallization ages

S. Siegesmund $(\square)$

Geoscience Centre of the Georg-August University Göttingen, Goldschmidtstr. 3, 37077 Göttingen, Germany

e-mail: ssieges@gwdg.de

\section{Basei}

Instituto de Geociências, Universidade de São Paulo,

Rua do Lago, 562, São Paulo CEP 05508-080, Brazil

P. Oyhantçabal

Departamento de Geología Facultad de Ciencias, Universidad de la República, Iguá 4225, C.P. 11400 Montevideo, Uruguay place the main magmatic events at 2.2-2.1 and 2.1-2.0 Ga. Dike swarms occurred in a tectonic setting of intraplate extension at ca. $1.7 \mathrm{Ga}$, and afterward the RPC remained unaffected by younger tectono-thermal events. Fig. 1

Several authors agree that the continents of the southern hemisphere have never been part of Rodinia (De Wit et al. 1999; Cordani et al. 2003). Nevertheless, the dispersal of this supercontinent is responsible for the convergence of cratons in the southern hemisphere, and therefore, the starting point of the amalgamation of Gondwana. As a consequence, active plate margins and orogenic belts developed at the margins of the RPC since ca. 0.9-0.8 Ga (Saalmann et al. 2007). The final amalgamation of Western Gondwana in the southeastern margin of the RPC may not have been complete until the Early Paleozoic after a protracted succession of convergence and the final collision of the cratons (Schmitt et al. 2008). Accretionary tectonics at the western margin of the RPC resulted in the collision of several Grenvillian terranes that may have lasted until the late Devonian (Varela et al. this volume).

\section{Contributions}

The 24 contributions comprising this special issue are divided into four general topics: (1) pre-Gondwana tectonics: the cratons; (2) tectonic evolution of Neoproterozoic-Eopaleozoic belts; (3) provenance and sedimentology of foreland successions; and (4) paleomagnetism, exhumation and cooling histories.

Pre-Gondwana tectonics: the cratons

Oyhantçabal et al. present a review of the Rio de la Plata Craton in Uruguay and recommend a redefinition 
Fig. 1 Cratons and cratonic fragments of South America and southwestern Africa

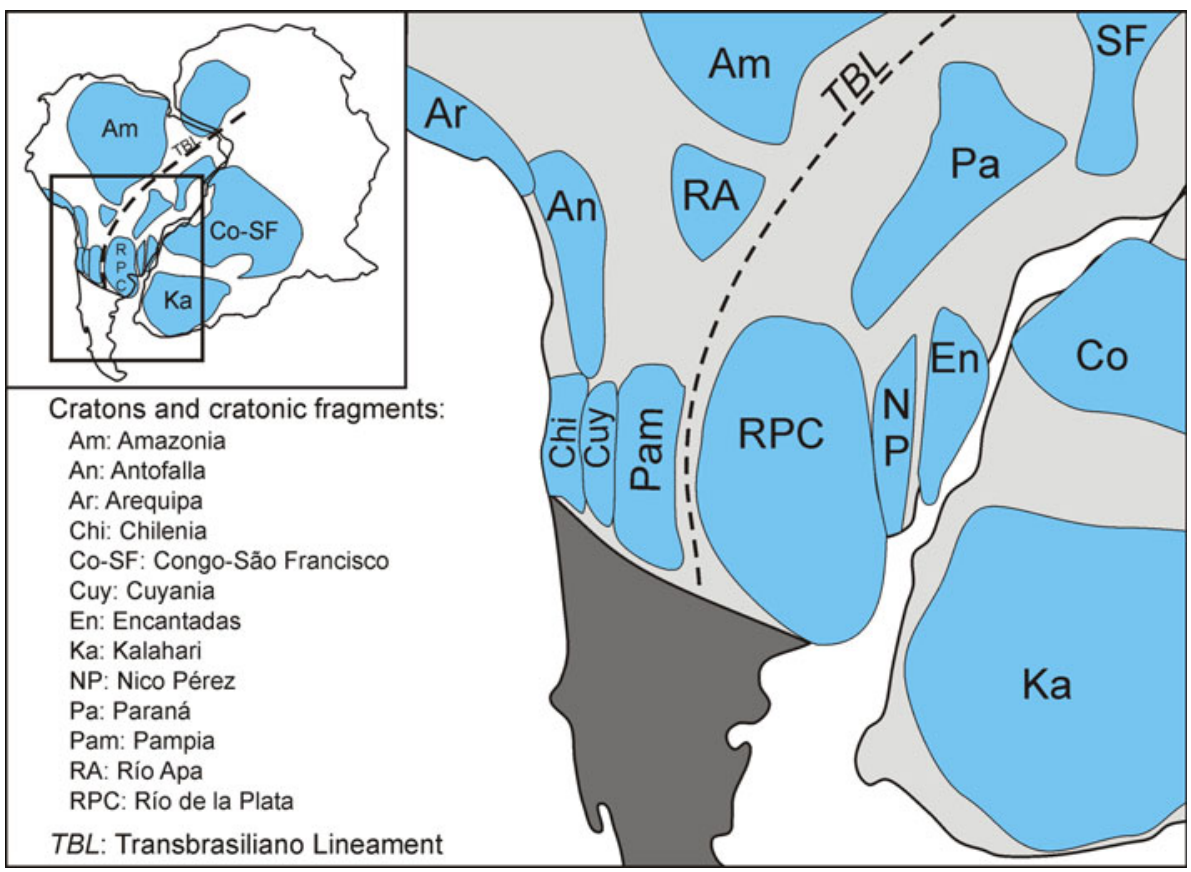

excluding the easternmost part, the Nico Pérez Terrane. The latter shows evidence of two main crustal growth episodes and of extensive Neoproterozoic reworking. Cingolani et al. describe the geology of the Tandilia Belt in Argentina comprising a Paleoproterozoic basement unaffected by latter tectonothermal events and an unmetamorphosed Neoproterozoic-Eopaleozoic cover. Therefore, this belt fits the revised definition of the RPC.

Varela et al. present a review of the Mesoproterozoic terranes attached at the western margin of the RPC. They conclude that the Maz Terrane shows features resembling the Amazon Craton, while Cuyania and Chilenia terranes show Laurentian affinity.

A complex scenario is observed in the basement inliers of the Dom Feliciano Belt. Saalmann et al. indicate that the Encantadas block or microcontinent, characterized by reworking of Neoarchean to Palaeoproterozoic crust and probably of African affinity, collided with the Rio de la Plata Craton at 0.8-0.7 Ga. Gaucher et al. report Mesoproterozoic magmatism in supracrustal successions of the Nico Pérez Terrane. Basei et al. present data for the basement of the Dom Feliciano Belt in southeastern Uruguay (the Punta del Este Terrane), confirming that this unit represents an allochthonous African domain. Furthermore, Luft et al. show evidence of an exotic 1.8-1.7 Ga terrane in the Kaoko Belt (the Mudorib Complex) imbricated between rocks of the Congo Craton. Together, these contributions show that several small allochthonous and para-autochthonous blocks were involved in the collision between the major cratons.
Tectonic evolution of Neoproterozoic-Eopaleozoic belts

From ca. 700 to $550 \mathrm{Ma}$, successive amalgamation processes occurred in southwestern Africa and southeastern South America, resulting in the formation of several orogenic Brasiliano/Pan-African belts. On the western side of the Rio de la Plata Craton, subduction and subsequent collisions of the Pampa, Cuyania and Chilenia Terranes resulted in a complex orogenic evolution beginning at the Ediacaran to Mid-Cambrian and ending in the Devonian (Schwartz et al. 2008; Steenken et al.). Frimmel et al. provide a review of the geodynamic evolution of southwestern Gondwana and conclude that Neoproterozoic extension produced several fragments of Rio de la Plata and Kalahari Cratons, which were re-amalgamated afterward. Remnants of the oceanic crustal material formed in back-arc basins related to this tectonic process are observed in the Marmora Terrane of the Gariep Belt.

Saalmann et al. discuss the geology of the São Gabriel Block, so far the only juvenile Neoproterozoic unit recognized in western Gondwana. They describe a protracted Brasiliano evolution that begins with extension at 800-700 Ma and finishes at ca. $530 \mathrm{Ma}$ with post-orogenic magmatism and reactivation of shear zones.

Oyhantçabal et al. demonstrate the correlation between the sinistral transpression in the Kaoko Belt (KB) and the Dom Feliciano Belt (DFB). The Sierra Ballena shear zone (DFB) and the Purros shear zone (KB) show comparable kinematics, deformation conditions of their mylonitic rocks and the timing of activity. 
Passarelli et al. apply an escape tectonic model addressed to the kinematics and the geochronological constraints of the major transpressional shear zones present at the eastern margin of the Rio de la Plata and Paranapanema cratons, where they are correlated to the final steps of Gondwana amalgamation. Ulrich et al. present detailed structural data combined with geochronology, providing evidence of sinistral transpression partitioned into domains of oblique thrusting and transcurrent sinistral shearing since $550 \mathrm{Ma}$ in the Kaoko Belt.

Chemale Jr. et al. document early S-type, late I-type and A-type magmatism to the late to post-orogenic granitic magmatism at $540-510 \mathrm{Ma}$ in the Saldania Belt. S- and I-type granites show juvenile as well as inherited crustal signatures, while A-type granites have a typical juvenile signature.

Lucassen et al. give evidence for medium temperature/ medium-high-pressure metamorphism in the Early Paleozoic at the active continental margin of West Gondwana in the Andes (NW Argentina/N Chile).

Steenken et al. update the metamorphic and magmatic evolution of the Eastern Sierras Pampeanas concerning three main orogenic cycles: the Pampean (Neoproterozoic to early Cambrian), the Famatinian (late Cambrian-Ordovician) and the Achalian (Devonian).

\section{Provenance and sedimentology of foreland successions}

Zimmermann et al. demonstrate the contribution from a magmatic arc in the Cerro Negro Formation of Tandilia and suggest that it may represent the record of a retroarc basin of the Terra Australis Orogen established at the Gondwana margin. Moreover, Zimmerman et al. question the glacial origin of the diamictites of the Witpus section of the Gariep Belt and caution on the consideration of this outcrop as evidence for a Late Neoproterozoic global glaciation.

Fourie et al. report geochemical and detrital zircon data for the Cape Supergroup in South Africa. They conclude that the observed major contribution from the NamaquaNatal Belt indicates an orographic barrier impeding contributions from the Kalahari or Kaapvaal cratons. Some Archean to Paleoproterozoic contributions can be traced from the Rio de la Plata Craton until the Carboniferous.

Basei et al. present a detailed geological map of the Itajaí Basin (Dom Feliciano Belt) and conclude that it is a foreland basin totally developed during Ediacaran time. $\mathrm{Nd}, \mathrm{Sr}$ and $\mathrm{Pb}$ isotopes indicated a shift in the sedimentary provenance with the basal continental units derived from the Luis Alves Craton, while the sediments of the upper marine units originated from the Dom Feliciano Belt.

For the Sierra Grande Formation and the upper part of the Ventana Group (North Patagonian Massif), Urzi et al. could show that the sedimentary sources are CambrianOrdovician and Neoproterozoic in age. The detrital source reflects a Western Gondwana provenance.

Paleomagnetism, exhumation and cooling histories

Zambrano et al. use paleomagnetic data to calculate sedimentation rates in the broken foreland of west Argentina. Lower Paleozoic granitic boulders occurring in conglomerates of this basin confirm the Miocene unroofing of the basement in the NW Sierra Pampeanas. Spagnoulo et al. reinterpret the rotation of blocks and terranes in NW Argentina as due to the collision of pre-Cordillera during Ordovician times.

Miller et al. present data on detrital zircons from the sedimentary successions of NW and central Argentina. These authors attribute the detrital zircon $\mathrm{U}-\mathrm{Pb}$ ages between 1,200 and $900 \mathrm{Ma}$, to a possible source in the Sunsás Orogen, while those between 670 and 545 Ma to the Brasiliano belts of SW and south-central Brazil. Paleoproterozoic detrital zircons only observed in the Late Cambrian and Early Ordovician formations suggest the Rio de la Plata Cratonic basement was hidden beneath the late Neoproterozoic and Early Cambrian cover before the Late Cambrian.

Drobe et al. use major- and trace-element geochemistry, $\mathrm{Sm}-\mathrm{Nd}$ and $\mathrm{Pb}$ isotopic data and U-Pb SHRIMP geochronology to decipher the provenance and to provide a new model for the geotectonic evolution of the Eastern Sierras Pampeanas.

Löbens et al. investigate the exhumation of the Sierras Pampeanas and convincingly demonstrate that most of the uplift observed in this area is not related to the propagation of flat-slab subduction but to Permo-Triassic tectonic events.

\section{Conclusion}

Neoproterozoic-Eopaleozoic agglutination around the Rio de la Plata Craton shows a complex history involving numerous different geological processes. Nevertheless, the broad approaches of the contributions published in this special issue document the considerable advances made in the knowledge of these two continental regions. We hope these contributions may inspire new lines of research for future investigations.

Acknowledgments We are especially grateful to the Editor-inChief of the International Journal of Earth Sciences, Prof. WolfChristian Dullo, for having supported the idea of this special issue and to all the reviewers, for their critical and constructive evaluation of the contributions. 
Open Access This article is distributed under the terms of the Creative Commons Attribution Noncommercial License which permits any noncommercial use, distribution, and reproduction in any medium, provided the original author(s) and source are credited.

\section{References}

Cordani UG, D'Agrella-Filho MS, Brito-Neves BB, Trindade RIF (2003) Tearing up Rodinia: the neoproterozoic palaeogeography of South American cratonic fragments. Terra Nova 15:350-359

De Wit MJ, Thiart C, Doucouré M, Wilsher W (1999) Scent of a supercontinent: gondwana's ores as chemical tracers-tin, tungsten and the Neoproterozoic Laurentia-Gondwana connection. J Afr Earth Sc 28:35-51. doi:10.1016/S0899-5362(98) 00085-2
Saalmann K, Hartmann LA, Remus MVD (2007) The assembly of west gondwana-the view from the Rio de la Plata Craton. In: Linnemann U, Nance RD, Kraft P, Zulauf G (eds) The evolution of the Rheic Ocean: from Avalonian-Cadomian active margin to Alleghenian-Variscan collision. Geological society of America. Special Paper 423, 1-26. doi:10.1130/2007.2423(01)

Schmitt RS, Trouw RAJ, Van Schmus WR, Passchier CW (2008) Cambrian orogeny in the Ribeira Belt (SE Brazil) and correlations within West Gondwana: ties that bind underwater. Geological Society, London, Special Publications; 294:279-296. doi:10.1144/ SP294.15

Schwartz JJ, Gromet LP, Miró R (2008) Timing and duration of the calc-alkaline arc of the pampean orogeny: implications for the late neoproterozoic to cambrian evolution of Western Gondwana. J Geol 116:39-61 